\title{
A economia política do conteúdo local no setor petrolífero de Lula a Temer *
}

\author{
Giorgio Romano Schutte ${ }^{* *}$
}

\begin{abstract}
Resumo
O setor petrolífero tem uma vasta experiência com políticas de Conteúdo Local (CL), em particular na Noruega. No Brasil, essa política ganhou força nos governos Lula da Silva, mas começou a sofrer desgaste nos governos de Dilma Rousseff. A tentativa de repactuar aspectos dessa política em 2015 chegou tarde e, no governo Temer, sofreu um rebaixamento considerável. O objetivo deste artigo é entender a facilidade política e a rapidez com as quais o processo se deu, a partir de dois fatores. Primeiro, a tempestade perfeita que atingiu a Petrobras em meados de 2014 e em 2015, com uma forte queda de preço do petróleo e os impactos da Operação Lava Jato e outros fatores. Segundo, o desgaste ao qual a política de Conteúdo Local foi submetida, identificada como parte do problema, e não da solução, para o desenvolvimento brasileiro. A partir de uma análise das medidas governamentais e do posicionamento dos atores relevantes, percebe-se que a política de Conteúdo Local foi sacrificada no intuito atrair operadoras internacionais.
\end{abstract}

Palavras-chave: Conteúdo local, Petróleo e Gás; Governo Temer; Pré-Sal, Brasil.

\begin{abstract}
The political economy of local content requirements in the oil sector from Lula to Temer

The oil sector has vast experience with local content requirements, particularly in Norway. In Brazil this policy gained force during the Lula administration, but suffered during Rousseff's administration, especially at the end of her first term. An attempt to rethink some aspects of this policy in 2015 come too late and under Temer's government it lost all importance. The objective of this article is to analyze the relative political ease with which this occurred taking into consideration two factors. First the perfect storm which struck Petrobras from mid-2014 and in 2015 causing a sharp fall in oil prices and the impact of Lava-Jato, among other factors. Second, the difficulties, which were attributed to this policy, criticized as being part of the problem and not of the solution for Brazil's development challenges. Based on analyses of governmental measures and the positioning of relevant stakeholders we learn that local content policy has been sacrificed in order to attract international operators.
\end{abstract}

Keywords: Local content requirements, Oil and Gas, Temer administration, Pre-Salt, Brazil. JEL L52, O14, Q48.

\section{Introdução}

Este artigo aborda um dos pilares da política industrial dos governos dos presidentes Luiz Inácio Lula da Silva e Dilma Rousseff, o Conteúdo Local na exploração e produção de Petróleo e Gás $(\mathrm{P} \& \mathrm{G})$. A prioridade dada ao CL esteve muito presente desde o início do governo Lula (2003), tendo recebido uma importância ainda maior com as descobertas do Pré-Sal, a partir de 2007.

O que se busca é entender a facilidade e a rapidez com que o governo Michel Temer (20162018) conseguiu desmontar essa política. A tese a ser explorada é a de que, por vários motivos, tal

\footnotetext{
${ }^{*}$ Artigo recebido em 24 de maio de 2020 e aprovado em 17 de julho de 2020. Contou com o apoio do Conselho Nacional de Desenvolvimento Científico e Tecnológico (CNPq) e da Coordenação de Aperfeiçoamento de Pessoal de Nível Superior (CAPES) - Código de Financiamento 001.

** Professor Associado da Universidade Federal do ABC (UFABC), São Bernardo do Campo, SP, Brasil. E-mail: giorgio.romano@ufabc.edu.br. ORCiD: https://orcid.org/0000-0002-5225-469X. O autor agradece os comentários valiosos de Marcos Antonio Macedo Cintra, Maria Luiza Levi Pahim e do revisor anônimo.
} 
política já estava desgastada, e os opositores souberam aproveitar da crise que tomou conta da Petrobras. Serão analisados dois fatores considerados cruciais para entender este processo. Primeiro, a desorganização de toda a cadeia a partir da tempestade perfeita que atingiu a Petrobras no segundo semestre de 2014, com o simultâneo impacto da Operação Lava Jato, com a consequente instabilidade política que se instalou no país, e da queda brusca do preço do petróleo e a desvalorização cambial. A se somar ao cenário descrito, a partir do governo Dilma, passou a existir uma forte articulação para alterar as políticas de produção vigentes no setor.

O segundo fator é o desgaste da própria política de CL, devido a equívocos e excessos em sua implementação. Contrária a outras experiências, em particular à norueguesa, a experiência posta em prática não se firmou como uma política de Estado e restou identificada com uma escolha política dos governos do PT. Isso impediu que as falhas identificadas pudessem ser objeto de aperfeiçoamento sem que se abdicasse do compromisso com a política industrial posta em prática.

Para refletir sobre as mudanças promovidas no governo Temer, este artigo conta com cinco seções, incluindo a introdução e as conclusões. Na primeira, será apresentada uma breve contextualização do conceito de CL e a experiência norueguesa, seguida, na segunda, por uma análise das políticas adotadas em governos de centro-esquerda no Brasil. Na terceira seção, constará uma análise das alterações implementadas e o posicionamento de diferentes atores, finalizando com as conclusões.

A análise foi conduzida utilizando-se, em primeiro lugar, de revisão de literatura sobre as experiências nacional e internacional para descrever a política de CL e identificar as condições em que a teoria econômica admite estratégias desse tipo, com especial ênfase às políticas associadas à exploração de petróleo. Em segundo lugar, foram empregados dados da Agência Nacional de Petróleo e Gás (ANP) para caracterizar a política de CL adotada no Brasil na indústria petrolífera em diferentes momentos, bem como alguns de seus efeitos. Finalmente, foram utilizados documentos publicados pelas entidades empresariais envolvidas, além de posições de representantes sobre a temática expostos entre 2015 e 2018, juntamente com relatos publicados na imprensa qualificada, de maneira a caracterizar o posicionamento dos diferentes players envolvidos.

\section{Requerimentos de conteúdo local - contextualização}

Os índices de CL estabelecidos por um governo, também conhecidos como índices de nacionalização, se referem à parte dos bens e serviços adquiridos para atividades de exploração e produção em um país que devem ser de origem nacional. O conceito de CL (em inglês: local content requirements) deve ser entendido como um instrumento de política industrial, que visa incrementar a participação do parque produtivo nacional em bases competitivas. Trata-se de uma política vertical, por ser focada em um setor específico ao longo de toda a cadeia que o compõe, ao contrário das políticas horizontais. Chang (2004a) relatou que a política de CL foi utilizada amplamente por países desenvolvidos quando em processo de desenvolvimento e continua sendo utilizada em setores classificados como estratégicos. Cabe observar que o uso de política de CL em países em desenvolvimento era discutido, em geral, em relação a investimentos externos diretos (por exemplo, em Chang, 2004b), mas, no caso do Brasil, era importante para garantir o adensamento das cadeias em torno de empresas nacionais, no caso, a Petrobras. 
Pode-se identificar três abordagens de valoração de CL. Em uma visão liberal, ela é rejeitada exatamente por ser uma política vertical e, enquanto tal, tenderia a gerar distorções no desenvolvimento produtivo, particularmente por pretensamente criar uma reserva de mercado a produtos de menor qualidade e preços maiores. Em uma segunda abordagem, o CL serve para corrigir falhas de mercado (Tordo; Warner; Manzano; Anouti, 2013), já que o próprio mercado não conseguiria garantir aumento da participação das empresas nacionais diante da expansão da demanda, por ineficiências em seu funcionamento. Sob tal perspectiva, a política de CL ajudaria a criar mercados eficientes. Na terceira abordagem, a partir de um ponto de vista desenvolvimentista, o desafio iria muito além da correção de falhas de mercado e estaria ligado ao esforço de catch-up (Chang, 2004b). Haveria um problema estrutural que exigiria um forte compromisso do Estado para garantir o aproveitamento da oportunidade para investimentos industriais, gerando escala, passando pela curva de aprendizagem e apropriando-se da capacidade tecnológica. Outro fator a ser considerado seria o impacto da exportação em grande volume de uma commodity como o petróleo sobre a taxa de câmbio, com subsequente tendência à desindustrialização ou ao constrangimento à industrialização. Assim, a política de CL faria parte de um esforço para conter o impacto da chamada doença holandesa ${ }^{1}$. Para tanto, exigiria a identificação do hiato entre a capacidade de oferta da indústria nacional em um setor e a demanda de bens e serviços do mercado, seguido pela criação de planos específicos para aumentar e melhorar a oferta. Por causa disso, na maioria dos casos, a política de CL é também de atração de empresas estrangeiras para determinados segmentos, com potencial de contribuir com trajetórias de aprendizagem tecnológica ${ }^{2}$. Oferece, portanto, oportunidades e riscos, exigindo acompanhamento e monitoramento dos vários processos, para gerar contínuo aperfeiçoamento e correção. Também está implícito no conceito que, sem sua aplicação, haveria aumento das importações, o que, em um primeiro momento, poderia até trazer benefícios em termos de preços e eficiência. A médio e longo e prazo, porém, haveria vazamento e perda do efeito multiplicador. Nesse sentido, de fato, "Local content policies are in essence a trade-off between shortterm efficiency and long term economic development" (Tordo et al., 2013, p. 10). Está implícito que o CL não pode se tornar um objetivo em si, mas sim visto como meio para atingir objetivos relacionados ao desenvolvimento industrial-tecnológico. A definição desses objetivos é, portanto, crucial para o desenho e a avaliação da política posta em prática.

A política de CL, por definição, refere-se a determinada cadeia de produção e valor, pressupondo seleção e identificação de oportunidades muitas vezes ligadas à existência de uma realidade específica, que abre a oportunidade de crescimento do setor. No caso do Brasil, a oportunidade concreta era identificada a partir das reservas de petróleo, sobretudo a partir das descobertas do Pré-Sal. A exploração e produção offshore é intensiva em capital, com grande potencial de geração de emprego e renda na cadeia de fornecimento. Isso explica também que o setor petrolífero tenha acumulado experiência internacional com CL, em particular a partir da exploração de P\&G no Mar do Norte, na década de 1970, pela Noruega.

(1) Esse fenômeno foi descrito com muita clareza por Celso Furtado na década de 1950, caracterizando-o como "subdesenvolvimento com abundância de divisas", ao refletir sobre o caso da Venezuela (Furtado, 2008). Mais tarde, a revista The Economist projetou esse conceito sobre a realidade da economia holandesa, a partir da exploração do gás no norte do país na década de 1960, cunhando a expressão "doença holandesa" (Schutte, 2010).

(2) No caso do Brasil, CL se refere à produção no território nacional independentemente da origem do capital. Em alguns outros casos, o conceito implica priorizar capital de origem nacional. 


\subsection{A experiência norueguesa}

A experiência norueguesa inspirou os formuladores da política de CL e a própria alteração do marco regulatório promovido pelo governo Lula em 2010. Curiosamente, a própria experiência se tornou referência crítica para os opositores da mesma política ${ }^{3}$.

A partir da exploração de petróleo no Mar do Norte na década de 1970, houve uma forte intervenção estatal que visava maximizar o aproveitamento das novas riquezas. Tratava-se especificamente de uma tentativa de estimular o adensamento das cadeias produtivas nacionais. $\mathrm{O}$ governo norueguês entendia que a mera existência da demanda não iria garantir o desenvolvimento vertical do setor, sendo necessário que se lançasse mão de políticas industriais específicas para o aproveitamento pleno da janela de oportunidade. Havia se criado desde o início um consenso na sociedade norueguesa em torno deste entendimento, processo facilitado pela estabilidade política do país. Em outras palavras, a política de Conteúdo Local era vista como uma estratégia de Estado, e não do governo de plantão, podendo ser, portanto, objeto de correções e ajustes, sem gerar questionamentos de motivação política que levariam a interrupções bruscas do rumo. Em 1971, o governo criou as estatais Statoil e Norwegian Petroleum Directorate, esta última responsável pelo direcionamento geral das políticas em torno da exploração de petróleo. A Statoil atuava como coordenadora do esforço nacional e do apoio tecnológico aos fornecedores locais. A estatal participava de todos os campos produtivos autorizados naquele período, isoladamente ou em parceria com outras empresas, garantida participação mínima de 50\% nos direitos do empreendimento no período de 1972 e 1992 (Pompermayer, 2011). Ao mesmo tempo, o governo tinha garantido o controle acionário do conglomerado NorskHydro, que por meio da sua divisão de petróleo participou da exploração do mega-campo de Ekofisk, entre outros (Hatakenaka et al., 2006). Foi criada ainda a estatal Petoro, para gerenciar os interesses financeiros do Estado na exploração do P\&G.

O que tornou esta experiência particularmente relevante para a discussão sobre CL é o fato de que o país conseguiu montar uma rede de fornecedores locais competitivos, partindo praticamente do zero. Heum (2008) relatou que quando a exploração de petróleo off-shore teve início no país, quase todas atividades eram feitas por empresas estrangeiras. Em 1972, um decreto estabeleceu a preferência por produtos e serviços locais. Leskinen et al. (2012) enfatizaram a importância dessa legislação, que estabeleceu a obrigação das operadoras em submeter ao governo a lista das empresas proponentes para contratos de fornecimento, facultando ao Estado priorizar empresas nacionais. Na prática, o Ministério de Petróleo e Energia (MPE) negociava diretamente com as operadoras para garantir a compra de bens e serviços de empresas locais em troca da concessão de novos campos de exploração. Um estudo sobre essa experiência a considerou amplamente exitosa, mas apontou a existência do trade-off: "During the late 1970s and early 1980s, local firms probably were chosen even if they were not the most cost effective" (Nordas; Vatne; Heum, 2003, p. 57). Com isso, o índice

(3) Em todo caso, há de se considerar as grandes diferenças entre as realidades brasileira e norueguesa: ao contrário do país sulamericano, a Noruega já era um país bastante desenvolvido, com um nível educacional elevado e uma trajetória institucional e política caracterizada pela busca de consenso e coesão social. Além disso, sua população era e é muito inferior à do Brasil. Com grande parte das instalações da cadeia petrolífera concentradas em uma única cidade, Stavanger, gerando fortes economias de aglomeração (Hatakenaka et al., 2006). Por fim, a indústria naval norueguesa já tinha projeção internacional, o setor de petróleo restando por ocupar uma centralidade na economia e política da nação muito superior à que se observaria no Brasil. 
de CL aumentou rapidamente, de 28\% no início da década de 1970, para 62\% em 1978 (Thurber; Istadd, 2010).

Ao longo do tempo, o setor se consolidou no país. Uma prova é o número de empregos diretos gerados, que chegaram 114 mil em 2009, o que equivale a cinco vezes as vagas criadas nas operadoras, ocupantes da ponta da cadeia (Sasson; Blomgren, 2001, p. 18). Parte do esforço do governo se deu também para integrar a indústria naval e a de construção, possibilitando a fabricação local de plataformas (Hatakenaka et al., 2006).

Nas seções seguintes, poderá se verificar que o que foi exposto até agora teve em linhas gerais correspondências com a experiência brasileira. O mesmo não ocorre no caso de outra característica da intervenção estatal na Noruega: a priorização e o foco na inovação e qualificação tecnológica da rede de fornecedores locais, com sua consequente internacionalização. Ou seja: o objetivo não era somente nem prioritariamente a geração local de emprego e renda no curto prazo. O governo começou a exigir das operadoras projetos para o desenvolvimento de competência de fornecedores locais. A partir do final da década de 1970, no mínimo 50\% das atividades de P\&D passaram a ser obrigatoriamente realizadas em entidades norueguesas (Heum, 2008). Em 1979, o governo introduziu os chamados Goodwill Agreements com as operadoras internacionais, por meio dos quais essas ganharam pontos ao contratar $\mathrm{P} \& \mathrm{D}$ em instituições norueguesas. Esses pontos serviriam como bônus para a outorga de campos de concessão. A transferência de tecnologia era valorizada até mais do que aportes financeiros. Ao mesmo tempo, houve fortes investimentos para criar novas instituições de pesquisa e capacitação, integradas com todos os elos da cadeia: as operadoras, os fornecedores de equipamentos e as empresas de serviços de engenharia. Oliveira e Rocha (2009) consideram que os laços criados entre as universidades e os fornecedores locais foram determinantes para o êxito da política praticada. Heum (2008) identifica como um dos indicadores deste sucesso o aumento gradual da participação internacional no faturamento das empresas fornecedoras norueguesas, que atingiu 29\% em 1995. Esse número se expandiu para $46 \%$ em $2005^{4}$.

Por último, mas não menos crucial, foi o apoio estatal à formação de companhias de serviços integrados, conhecidas como EPC (Engenharia, Suprimento e Construção), ou para-petrolíferas. É um segmento dominado globalmente por três grandes players estadunidenses: Schlumberger, BakerHughes e Halliburton, mas com espaço para a atuação de empresas menores, mais especializadas. A Noruega entendeu a importância de disputar esse setor, o que só seria possível se existissem players internacionais. Graças à política de CL implantada, eles passaram a existir, sendo a Aker-Kvaerner e a Vetco Aibel os exemplos que se tornaram mais conhecidos.

A literatura sobre CL costuma enfatizar a necessidade de projetar essas políticas em um horizonte de tempo, no sentido de ter embutido no seu desenho a sua cessão após certo tempo, para evitar acomodação e estimular os fornecedores a se tornaram competitivos. No caso da Noruega, a

(4) Há de se observar as limitadas reservas da Noruega. A partir de 2010, a produção de petróleo no Brasil já superou a da Noruega e, a partir de então, a primeira continuou crescendo, enquanto a última ficou estagnada, com tendência de baixa. Isso evidentemente reforçou a noção da urgência de internacionalização. 
maior abertura e a eliminação dos incentivos específicos se deu muito em função das exigências da Comunidade Europeia em $1996^{5}$.

\subsection{A experiência brasileira até o governo Lula}

No Brasil, a Petrobras tinha o monopólio de exploração e produção até a entrada em vigor da Lei do Petróleo (9.478/1997). Antes disso e desde a sua criação, em 1953, a política de compras da companhia se dava em um contexto nacional-desenvolvimentista, que foi fundamental para o surgimento de um parque nacional de produção de equipamentos e serviços. Primeiro, com destaque para a construção de um parque de refino que contribuiu inclusive para o surgimento do setor de bens de capitais. Já a partir da década de 1980, as reservas descobertas em águas cada vez mais profundas significaram uma nova fronteira para a cadeia de fornecedores.

A Lei do Petróleo não tratou da política industrial para o setor, mas introduziu mecanismos brandos para a defesa da indústria nacional diante do processo de abertura que formatava, muito sob pressão da indústria, em particular da Federação das Indústrias do Estado do Rio de Janeiro (Firjan). Evitou-se, porém, qualquer sugestão de medidas compulsórias ou de reserva de mercado, porque a prioridade era a atração das operadoras internacionais em um contexto de preços de petróleo baixos e risco exploratório razoável. (Fernandez; Fernandez, 2013). O resultado foi uma política de CL tímida, com índices gerais baixos e sem muita fiscalização. Na prática, a Petrobras diminuiu o CL de suas compras no âmbito da liberalização comercial. Além do mais, a Petrobras adotou uma política de terceirização, seguindo a tendência das grandes empresas privadas, que alcançou até mesmo atividades de inovação e de engenharia. Ao mesmo tempo, houve o impacto negativo da sobrevalorização do real, resultante da âncora cambial.

Assim, quem mais se beneficiou com as crescentes ofertas contratuais e de negócios da Petrobras foram as empresas para-petrolíferas internacionais, que já tinham a sua estrutura de fornecedores (Negri, 2010), em detrimento da estrutura de fornecedores locais. Furtado et al. (2003) apontam uma desnacionalização pela ausência de empresas locais com capacidade financeira e tecnológica para assumir os novos contratos. Coerente com uma visão liberal, a equipe econômica do governo de turno forçou a Petrobras a se comportar como uma empresa privada. $\mathrm{O}$ fomento da indústria nacional perdeu prioridade. Em paralelo, o governo lançou, em 1999, o Regime Aduaneiro Especial de Exportação e Importação de Bens Destinados às Atividades de Pesquisa e de Lavra das Jazidas de Petróleo e de Gás Natural (Repetro), que permitiria, durante sua vigência de vinte anos, a importação de equipamentos específicos sem a incidência dos tributos federais.

\section{O conteúdo local nos governos Lula e Dilma}

No governo do presidente Lula, a política de CL passou por mudanças quantitativas e qualitativas. Em primeiro lugar, houve desde 2003 um aumento significativo de seus índices, como pode ser observado na Tabela 1. A média de CL aumentou de 33,5\% na exploração e 42,25\% no desenvolvimento nas primeiras quatro rodadas de licitação exploratória para 79,6\% e 85,3\% nas três

(5) A Noruega nunca foi membro da União Europeia, mas se relaciona com o Mercado Comum por meio do Acordo do Espaço Econômico Europeu e, na pratica, está submetida às mesmas regras desde 1994. 
rodadas seguintes. Observe-se que essa alteração na política se deu anteriormente à descoberta do Pré-Sal.

Tabela 1

Médias de CL nas rodadas de licitações para exploração e produção de petróleo e gás natural entre 1999 e 2015

\begin{tabular}{c|c|c|c}
\hline Rodada & Ano & Fase de exploração & Fase de desenvolvimento \\
\hline $1^{\mathrm{a}}$ & 1999 & 25 & 27 \\
\hline $2^{\mathrm{a}}$ & 2000 & 42 & 48 \\
\hline $3^{\mathrm{a}}$ & 2001 & 28 & 40 \\
\hline $4^{\mathrm{a}}$ & 2002 & 39 & 54 \\
\hline $5^{\mathrm{a}}$ & 2003 & 79 & 86 \\
\hline $6^{\mathrm{a}}$ & 2004 & 86 & 89 \\
\hline $7^{\mathrm{a}}$ & 2005 & 74 & 81 \\
\hline $9^{\mathrm{a}}$ & 2007 & 69 & 77 \\
\hline $10^{\mathrm{a}}$ & 2008 & 79 & 84 \\
\hline $11^{\mathrm{a}}$ & 2013 & 62 & 76 \\
\hline $12^{\mathrm{a}}$ & 2013 & 73 & 84 \\
\hline $13^{\mathrm{a}}$ & 2015 & 73 & 80 \\
\hline
\end{tabular}

Fonte: ANP (s.d.).

Em segundo lugar, por meio do Decreto n. 4.925/2003, o governo instituiu o Programa de Mobilização da Indústria Nacional de Petróleo e Gás Natural (Prominp), estruturado como um fórum de articulação permanente, coordenado pelo Ministério de Minas e Energia (MME) e pela Petrobras. $\mathrm{O}$ foco era o desenvolvimento de ações concretas visando maximizar a participação da indústria nacional de bens e serviços, em bases competitivas e sustentáveis, em projetos de petróleo e gás natural no Brasil e no exterior. O Prominp deu uma grande contribuição para a capacitação da mãode-obra e realização de estudos de competitividade da cadeia de fornecedores, em particular no segundo governo $\mathrm{Lula}^{7}$.

Em terceiro, a política de CL, sobretudo a partir da $7^{a}$ Rodada de Licitações, em 2005, ganhou em rigor e complexidade, com o estabelecimento de índices obrigatórios e com limites mínimos e máximos ${ }^{8}$. Foram criadas diferenciações por itens e subitens, com uma metodologia elaborada pelo Prominp para identificação da origem de fabricação dos componentes de cada equipamento e do valor dos insumos importados em comparação com o valor total, tudo colecionado em um documento técnico-regulatório: a Cartilha de Conteúdo Local (FIEB, 2015).

(6) Lembrando que a $8^{a}$ Rodada foi cancelada a partir de uma ação promovida pela Frente Única dos Petroleiros (FPU).

(7) O programa perdeu sua força, foi interrompido pelo governo Temer e extinto pelo governo Bolsonaro por meio do Decreto n. 10.087 de 5 de novembro de 2019.

(8) A introdução do nível máximo era justamente para evitar ofertas irreais com o único objetivo de ganhar a licitação para depois ficar sujeito a multas pelo não cumprimento. Não obstante o uso dos valores máximos, esse problema iria aparecer ao longo das rodadas. 
Em quarto, o governo criou um sistema de fiscalização, exigindo, a partir da $7^{\text {a }}$ Rodada de Licitações, uma certificação emitida por empresa independente credenciada pela ANP ${ }^{9}$, que instituiu, em abril de 2007, a Coordenadoria de Conteúdo Local (CCL).

Sem dúvida, havia um custo de transação no processo, e sua complexidade se tornaria ao longo dos anos um dos principais alvos de crítica. A princípio, tentou-se evitar excessiva rigidez, possibilitando o uso de critérios de exceção quando a norma não fosse aplicável nas condições do mercado local ou quando não fosse razoável exigir a sua aplicação (waiver ${ }^{10}$. No entanto, o uso excessivo do waiver e os critérios arbitrários utilizados para sua concessão se tornariam uma referência para desmoralizar a política de CL, o que chegou a motivar um processo administrativo no Tribunal de Contas da União (TCU).

Com o advento da descoberta e exploração Pré-Sal, a consequente grande ampliação dos investimentos - que já eram enormes - da Petrobras e das demais operadoras do setor poderiam implicar em aumento brutal das importações ou, com a aplicação eficiente de uma política de CL, na criação de capacidade produtiva nacional, com desenvolvimento vertical de toda a cadeia industrial. Seria necessário, para tanto, a adoção de políticas públicas seletivas para se aproveitar as oportunidades e garantir que o crescimento esperado qualificasse a base produtiva ao ponto de tornála competitiva até no mercado internacional, como ocorreu na Noruega.

A Lei n. 12.351, de 22 de dezembro de 2010, que alterou o marco regulatório para a exploração nas áreas do Pré-Sal, deu para o Conselho Nacional de Política Energética (CNPE) a atribuição de "induzir o incremento dos índices mínimos de conteúdo local de bens e serviços" política de CL ganhou, portanto, uma relevância superior ao sair do âmbito considerado mais técnico da ANP para o do CNPE, órgão interministerial coordenado pelo MME, de caráter político, que ganhou força em detrimento da Agência. Em seu artigo 9, inciso I, a lei deixou clara a centralidade dada naquele momento à política industrial, ao condicionar o ritmo de contratação dos blocos exploratórios sob o regime de partilha de produção "à capacidade da indústria nacional para o fornecimento de bens e serviços". Na mesma linha, a obrigatoriedade de a Petrobras ser operadora única na província do Pré-Sal e de deter no mínimo 30\% dos consórcios deveria garantir o seu protagonismo nas principais decisões operacionais, dentre elas, toda a política de compras. A escala e a perspectiva temporal, que justificavam pensar em um mercado grande por muito tempo, reforçaram muito essa aposta.

Com isso, surgiu a possibilidade, por exemplo, de reativar o setor naval, que passaria por uma nova curva de aprendizagem, para gerar uma capacidade produtiva que pudesse, em um segundo momento, tornar-se independente da demanda da Petrobras e concorrer internacionalmente. Isso

(9) As certificadoras se tornaram responsáveis por medir e informar à ANP o CL dos bens e serviços contratados pelas concessionárias. O processo de certificação devia ocorrer ao longo de toda a cadeia de suprimentos. O Relatório de Conteúdo Local era entregue trimestralmente para a ANP, junto com outra exigência contratual, o Relatório de Investimento.

(10) Os casos previstos nas normas da ANP eram: se o preço dos fornecedores locais fosse excessivamente alto em relação aos fornecedores internacionais; se o prazo de entrega, em comparação com os fornecedores internacionais, comprometesse a produção do petróleo; ou se a tecnologia não estivesse disponível internamente.

(11) Essa atribuição foi incluída na Lei n. 9.478/1997, a Lei do Petróleo como Inciso X do artigo 2. 
implicava na necessidade de se garantir mecanismos de financiamento para a ampliação da capacidade instalada, para a construção de plataformas, navios petroleiros e os próprios estaleiros.

No primeiro governo Dilma Rousseff (2011-2014), houve uma reafirmação da política de CL, em um contexto de rápida deterioração da balança comercial da indústria manufatureira, provocada por uma nova rodada de valorização da moeda, reflexo da entrada de fluxos financeiros ${ }^{12}$ e do acirramento da concorrência internacional, em particular gerado pela agressiva política chinesa de exportações ${ }^{13}$. O déficit na indústria de transformação chegou a US\$ 100 bilhões no biênio 2011 2012.

\subsection{Questionamentos à política de $\mathbf{C L}$}

Uma sondagem da Price \&WaterhouseCoopers (PwC) realizada em 2011 junto a fornecedores mostrou o dilema embutido na estratégia de CL. Cerca de $68 \%$ dos entrevistados eram a favor da política do governo com o argumento de que esta fortalecia a indústria, gerava empregos, estimulava transferência de tecnologia e qualificava a mão-de-obra. Ao mesmo tempo, $88 \%$ avaliaram que a política implicava aumento de custos, e cerca de 50\% acreditavam que a ANP não tinha condições de avaliar o cumprimento das exigências contratuais referentes às percentagens mínimas (PwC, 2012).

No mesmo ano, o TCU passou a questionar a capacidade da ANP de fiscalizar os contratos, sobretudo a partir da $7^{a}$ Rodada, "tendo em vista a grande mudança no método de aferição do CL." (TCU, 2011, p. 2). Ou seja, para a corte de contas, a maior complexidade do CL não tinha sido acompanhada por um aumento da capacidade institucional por parte da ANP.

Além disso, diante do aumento expressivo dos volumes arrecadados por meio da Cláusula de $\mathrm{P} \& \mathrm{D}^{14}$, tinha surgido uma crítica da Organização Nacional da Indústria de Petróleo (ONIP) ${ }^{15}$ às regras sobre o seu destino diante da necessidade de aumentar a capacidade tecnológica da rede de fornecedores (ONIP, 2008). A reclamação da indústria dizia respeito ao pouco retorno para a cadeia desses investimentos. No mesmo documento, a organização reclamou do contingenciamento sistemático dos recursos arrecadados pelo CP-PETRO ${ }^{16}$. Em 2012, a ONIP encaminhou à ANP uma

(12) Como reflexo da política de Quantative Easing (QE), por meio da qual o Banco Central dos EUA injetou liquidez que, em parte, veio parar em praças mais lucrativas para investir, caso do Brasil. Esse fenômeno foi chamado pelo então ministro da Fazenda, Guido Mantega, de "tsunami financeiro".

(13) Acima de tudo, a indústria chinesa queria manter sua posição. Diante da queda da demanda nos principais mercados da Europa e dos Estados Unidos, houve, entre outros, uma investida no Brasil, país que tinha crescido 7,5\% em 2010 e mantinha sua política de expansão de crédito e aumento do salário mínimo. E, adicionalmente, encontrava-se com sua moeda supervalorizada.

(14) A chamada cláusula de Pesquisa \& Desenvolvimento (P\&D) faz parte dos contratos de concessão desde a primeira Rodada. Por esta cláusula, as concessionárias dos campos de alta produtividade, ou seja, onde se aplicam as participações especiais, são obrigadas a investir $1 \%$ da sua receita bruta em P\&D, sendo metade do valor em instalações próprias e a outra em instituições científicas e tecnológicas, cadastradas e aprovadas pela ANP. Na prática, são sobretudo as universidades públicas de ponta.

(15) A Organização Nacional da Indústria do Petróleo nasceu em 1999 para ser a voz das empresas instaladas no Brasil com atividades nos diversos elos da cadeia de P\&G, tendo entre suas filiadas as principais federações da indústria (Firjan, Fiesp, Fieb, Fiemg, Findes) e a Sebrae. Em outro documento, a organização calculou que o Pré-sal iria abrir um mercado de investimentos potenciais de R\$ 400 bilhões entre 2010 e 2020, em setores de máquinas e equipamentos, construção naval, e vários serviços (ONIP, 2010, p. 7), mas alertava para o desafio de escala, de tecnologia e da capacidade para acompanhar o ritmo da demanda da Petrobras.

(16) CT-PETRO foi o primeiro Fundo Setorial, criado em 1999, com o objetivo de estimular a inovação na cadeia produtiva do setor de petróleo, gás natural e biocombustíveis, a formação e qualificação de recursos humanos e o desenvolvimento de projetos em 
proposta de alteração da norma para garantir que os 50\% reservados para instituições de pesquisa pudessem ser destinados também a empresas fornecedoras para projetos inovadores.

Críticas ao próprio conceito de CL vieram também dos EUA. O subsecretário de Comércio Internacional, Francisco Sanchez, por exemplo, criticou, no Fórum Econômico Mundial para América Latina, no Rio de Janeiro, em 28 de abril de 2011, a exigência de CL no Pré-Sal, argumentando que restrições à participação externa poderiam fazer o país abrir mão das melhores tecnologias disponíveis. O mesmo funcionário aproveitou a visita da presidente Dilma a Washington, para um seminário em abril de 2012, para contestar novamente as regras de CL utilizadas, que seriam barreiras à entrada no Pré-Sal (Peres, 2012). Essa posição foi expressa também pela Câmara de Comércio Americano do Rio (Lourenço, 2014) ${ }^{17}$.

Enquanto isso, na consulta pública realizada pela ANP entre 25 de janeiro e 4 de fevereiro de 2013 a respeito do edital para a $11^{\circ}$ Rodada (em terra e áreas pós-sal), o Instituto Brasileiro de Petróleo, Gás e Biocombustível (IBP), porta-voz das concessionárias privadas nacionais e principalmente estrangeiras, encaminhou uma sugestão de flexibilização das exigências de Conteúdo Local, alegando "a impossibilidade de se atingir os percentuais mínimos de conteúdo local em algumas rubricas". Posicionou-se criticamente sobretudo às exigências do edital para a fase de desenvolvimento, argumentando a "impossibilidade de prever a disponibilidade/capacidade e capacidade futura da indústria brasileira” (ANP, 2011).

Ao final, o aumento dos índices de CL se deu junto com um crescimento expressivo dos investimentos da Petrobras, de US\$ 11,6 bilhões ${ }^{18}$ ao ano em 2006 para US\$ 40 bilhões em 2013 (Petrobras, 2014). A expansão da indústria não teria sido capaz de acompanhar esse ritmo, um dos motivos do aumento do não cumprimento dos índices de $\mathrm{CL}^{19}$. Em nova audiência pública realizada ainda em 2013, a ANP deixou claro, por meio de sua diretora-geral, Magda Chambriard, que não iria rever as metas de CL: "A política de conteúdo local está sendo reafirmada. Estamos apostando na indústria brasileira e na continuidade das encomendas para a indústria naval. Nossa preocupação é garantir a perenidade dessas encomendas" (Polito, 2013). Porém, era inegável a essa altura que havia a necessidade de uma reavaliação da política de CL, no sentido de manter os objetivos originais. O início do segundo mandato da presidenta Dilma teria sido um momento propício para um

parceria entre empresas e universidades, instituições de ensino superior ou centros de pesquisa do País, visando o aumento da produção e da produtividade, a redução de custos e preços e a melhoria da qualidade dos produtos do setor. O Fundo Setorial CT-PETRO é mantido com $25 \%$ da parcela do valor dos royalties que exceder a $5 \%$ da produção de petróleo e gás natural.

A ONIPI (2008) criticou o fato que entre 1999 e 2007 os recursos arrecadados pelo CTPETRO foram da ordem de R $\$ 4,8$ bilhões, entretanto, apenas R \$ 600 milhões foram efetivamente despendidos dentro da finalidade do Fundo Setorial.

(17) Essas preocupações por parte do governo dos EUA já estavam presentes na discussão sobre o novo marco regulatório em 2009 e 2010, conforme pode ser averiguado no telegrama confidencial de 27 de agosto de 2009, vazado pelo wikileaks, do consulado dos Estados Unidos para o Departamento do Estado, Secretaria de Estado e Conselho Nacional de Segurança. Nele consta o relato de uma conversa do consulado com a diretora da ExxonMobil, Carla Lacerda, que alertava para as prováveis consequências de a Petrobras ser operadora única, "more control over equipment purchasses, personnel and technology selection ...which in turn could adversely affact US equipment and service supply to Brazil”' (Wikileaks, 2013).

(18) Em US dólar de 2013.

(19) Além de uma superavaliação da capacidade local, havia uma oferta excessiva por parte das petroleiras para ganhar as licitações devido ao fato que a oferta em termos de conteúdo local era um dos critérios utilizados pela ANP para rankear as propostas. (Senado Federal, 2017, p. 29). 
aggiornamento da política por parte do Executivo a partir de uma avaliação mais rigorosa e pactuada com os vários stake-holders, o que nunca ocorreu.

\subsection{Problemas identificados na literatura}

Logo no início da nova política para o CL no Brasil, a literatura já problematizava seus objetivos. Fernández y Fernández e Pedrosa (2003) defenderam a necessidade de diferenciar entre resultados de curto prazo (geração de emprego) e objetivos de mais longo prazo, visando alcançar competitividade da indústria, inclusive nos mercados internacionais. Para Furtado e Freitas (2004), a política de CL deveria representar um avanço com relação à industrialização por substituição de importações, ao colocar como objetivo central o aumento do domínio técnico local e a geração endógena de tecnologia.

Na segunda metade da década de 2000, Oliveira e Rocha (2011) fizeram no âmbito do Prominp um estudo de competitividade dos vários segmentos do complexo de fornecedores que iria se tornar uma referência. Os autores identificaram que o conjunto de setores estudados apresentava um déficit significativo de competitividade, vinculado fundamentalmente a uma fragilidade da engenharia nacional e uma limitada capacitação tecnológica para inovar. A principal diferença identificada com o modelo norueguês estava justamente na ausência de uma rede cooperativa de inovação, que deveria envolver a operadora, EPCistas, empresas de serviços, firmas industriais, universidades e centros de pesquisa no desenvolvimento da capacitação tecnológica. Os autores recomendaram ainda o desenvolvimento de capacidade de exportação, não somente como meta para alcançar competitividade, mas para fazer face à instabilidade temporal do ciclo de investimentos da indústria de $\mathrm{P} \& \mathrm{G}$. O problema era que o cronograma de investimentos da Petrobras até 2014 demonstrava ser, por si só, já um enorme desafio ${ }^{20}$.

Pompermayer (2011), em seu estudo de comparação entre as experiências norueguesa e brasileira, enfatizou outro aspecto: a necessidade de se pensar especificamente na qualificação de empresas de capital nacional. Ao não fazer uma destinação pelo capital de origem, a política de CL pode ser atendida por fornecedores internacionais, sobretudo nos segmentos de maior complexidade tecnológica, podendo inibir o desenvolvimento de expertise nacional. $\mathrm{O}$ argumento principal do autor é que as empresas de capital nacional, quando a exploração do Pré-Sal terminar, poderiam continuar gerando renda para o país, ao exportar o conhecimento aqui desenvolvido. Se fossem empresas estrangeiras, o conhecimento adquirido na exploração do Pré-Sal tenderia a gerar renda nos seus países de origem.

O papel central dado à Petrobras para a implementação de uma política vigorosa de Conteúdo Local, e a decisão estratégica de condicionar o ritmo dos investimentos no Pré-Sal à capacidade de oferta da cadeia nacional de fornecedores, foram criticados por setores liberais. Guimarães (2012), por exemplo, sugeriu que a Lei do Pré-sal teria significado de fato uma volta à situação existente durante o monopólio estatal, na qual a participação das fornecedoras se definia no âmbito da política de compras da Petrobras.

(20) Nesse caso os autores recomendaram que as empresas fornecedoras brasileiras acompanhassem o processo de internacionalização que estava em curso naquele momento (Oliveira; Rocha, 2011, p. 29). 
Vários autores retomaram as questões levantadas no estudo de Oliveira e Rocha (2011). Mendonça e Oliveira (2013) se perguntaram por que o Brasil não tinha conseguido desenvolver um cluster de empresas inovadoras, como a Noruega fez. Identificaram três elementos presentes na política de CL implementada no Brasil: falta de consenso, debilidade regulatória e arranjos que não estimulam a inovação ao longo da cadeia de fornecedores. Os autores enfatizam em particular a falta de integração dos fornecedores nos esforços tecnológicos da Petrobras junto com os centros de pesquisa.

Na mesma linha, Canêdo Pinheiro (2015) identificou a ausência de incentivos para investimento em inovação entre os fornecedores. $\mathrm{O}$ autor ainda questionou a falta de objetivos claros por parte do governo com a política de CL. Ao final, os índices de CL não deveriam ser um objetivo em si. Em princípio, essas políticas são desejáveis enquanto os benefícios sociais forem maiores do que as perdas. Por isso, inclusive, o autor critica o seu uso indiscriminado. Precisaria ser mais seletiva com um menor número de segmentos beneficiados e prazos para sua gradual desativação. Furtado e Ribeiro (2015) e Santos e Avellar (2017) tinham chegado também à conclusão de que a exigência de CL estava sendo perseguida sem uma necessária capacitação tecnológica dos fornecedores. As políticas apresentaram incoerências e não resultaram em aumento da competitividade das empresas envolvidas.

Em linhas mais gerais, em retrospectiva, um ex-assessor da presidência da Petrobras durante os governos Lula e Dilma, avaliou que "metas excessivamente ambiciosas foram além do limite da capacidade tanto da Petrobras quanto dos fornecedores, e desvirtuaram aquela que seria, conceitualmente, uma política virtuosa de estímulo à economia brasileira" (Ghirardi, 2015, p. 4).

Contudo, a maioria dessa literatura, com exceção evidentemente daquela inspirada por ideias liberais, entende conceitualmente a importância de uma política virtuosa de CL. As críticas e limitações poderiam ser entendidas como recomendações para um processo de ajuste da mesma.

\subsection{Tempestade perfeita}

A partir da segunda metade de 2014, dois fatores interligados alteraram drasticamente o quadro econômico e político do país. De um lado, o acirramento do conflito político e a tentativa de desmoralizar e desestruturar o governo Dilma, aproveitando-se das revelações devastadoras da Operação Lava Jato. De outro, a queda expressiva do preço do petróleo, que provocou uma paralisação dos investimentos no setor de $P \& G$ no mundo todo. Em 2015, houve ainda uma forte desvalorização cambial, que agravou a situação da Petrobras - com receitas em reais e compromissos em dólar. Essa combinação de fatores negativos resultou em um desastre: uma tempestade perfeita ${ }^{21}$.

Diante disso, houve sucessivas revisões dos investimentos programados pela empresa brasileira. Para demonstrar firmeza no combate à corrupção, a companhia tomou uma decisão que acabou agravando de imediato a situação econômico-financeira de seus fornecedores, subfornecedores e a da economia como um todo. Em 29 de dezembro de 2014, a empresa divulgou uma lista de 23 grupos, posteriormente ampliada para 27, que, por estarem sob investigação, seriam

(21) Há de se considerar ainda que a Petrobras se encontrou com alto grau de endividamento para dar conta do plano de investimentos ambicioso da empresa, graças à política de preços de combustíveis imposta pelo governo Dilma nos anos anteriores (Schutte, 2016). 
excluídos do rol de fornecedores. A adoção da medida cautelar teria por finalidade "resguardar a companhia e suas parceiras de danos de difícil reparação financeira e de prejuízos à sua imagem" (Petrobras, 2014). As referidas empresas foram temporariamente impedidas de serem contratadas e de participarem de licitações da Petrobras. O problema era que todas as principais construtoras brasileiras constavam nessa lista ${ }^{22}$. Houve uma paralisação generalizada ao longo da cadeia, que, devido ao fato de essas empresas estarem todas com endividamento elevado (justificado pela perspectiva de crescimento da demanda garantida nos próximos anos), gerou um impacto ainda maior sobre a economia brasileira. As agências de rating imediatamente rebaixaram a classificação de risco das empreiteiras envolvidas, complicando ainda mais o acesso ao crédito. O Gráfico 1 mostra a queda expressiva dos investimentos da Petrobras, que eram a âncora para uma política de CL vigorosa.

Gráfico 1

Investimento anual da Petrobras entre 2013 e 2016 em US\$ bilhões

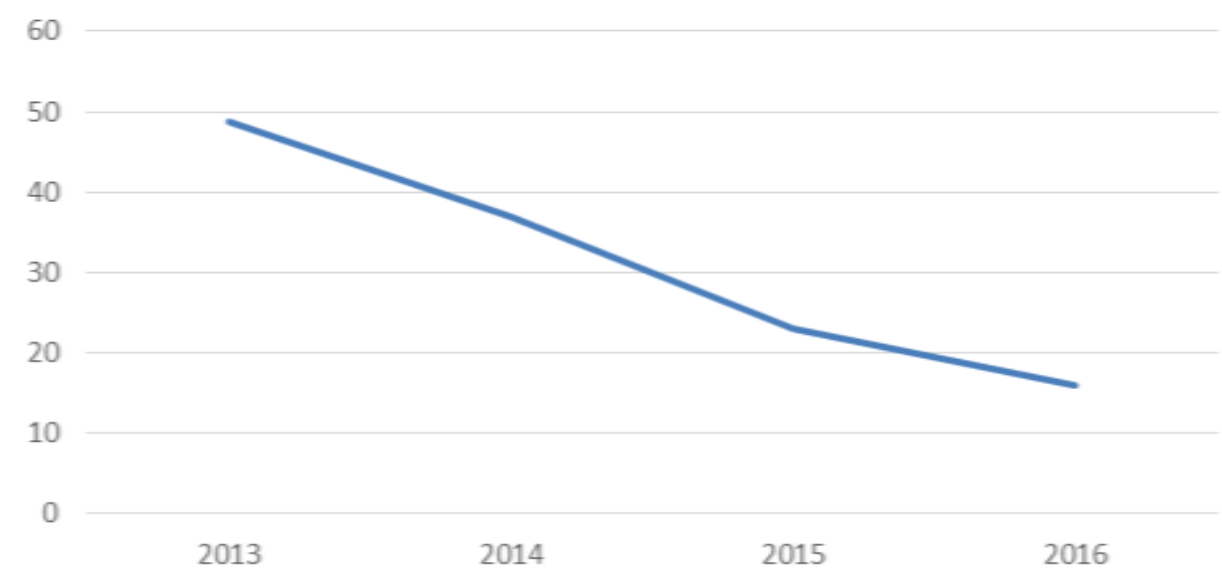

Fonte: Petrobras (https://www.investidorpetrobras.com.br/visao-geral/investimentos/).

Sergio Bacci, do Sindicato Nacional da Indústria de Construção e Reparação Naval e Offshore (Sinaval), enfatizou o que chamou de "choque entre os tempos político-jurídico e econômico". O impedimento de contratação das empresas nacionais não somente gerou uma paralisação e uma incerteza muito grande sobre o futuro imediato, mas levou automaticamente a Petrobras a modificar sua política de CL, aumentando as compras internacionais. Bacci (2015) calculou um impacto direto de perda de 200 mil empregos. A título de ilustração, o Gráfico 2 mostra a evolução do emprego direto na indústria naval no período entre 1970 e 2018 . O que explica o forte declínio é a queda na contração dos investimentos da Petrobras e a eliminação dos subsídios fiscais e financeiros para a indústria nacional.

(22) Conforme divulgado em 29 de dezembro de 2014, foram bloqueadas empresas pertencentes a 23 grupos: Alusa, Andrade Gutierrez, Camargo Corrêa, Carioca Engenharia, Construcap, Egesa, Engevix, Fidens, Galvão Engenharia, GDK, IESA, Jaraguá Equipamentos, Mendes Junior, MPE, OAS, Odebrecht, Promon, Queiroz Galvão, Setal, Skanska, TECHINT, Tomé Engenharia e UTC. Em 6 de março de 2015, foram bloqueadas também as empresas Schahin Engenharia e TKK Engenharia. 
Gráfico 2

Evolução emprego direto na indústria naval 1970-2018

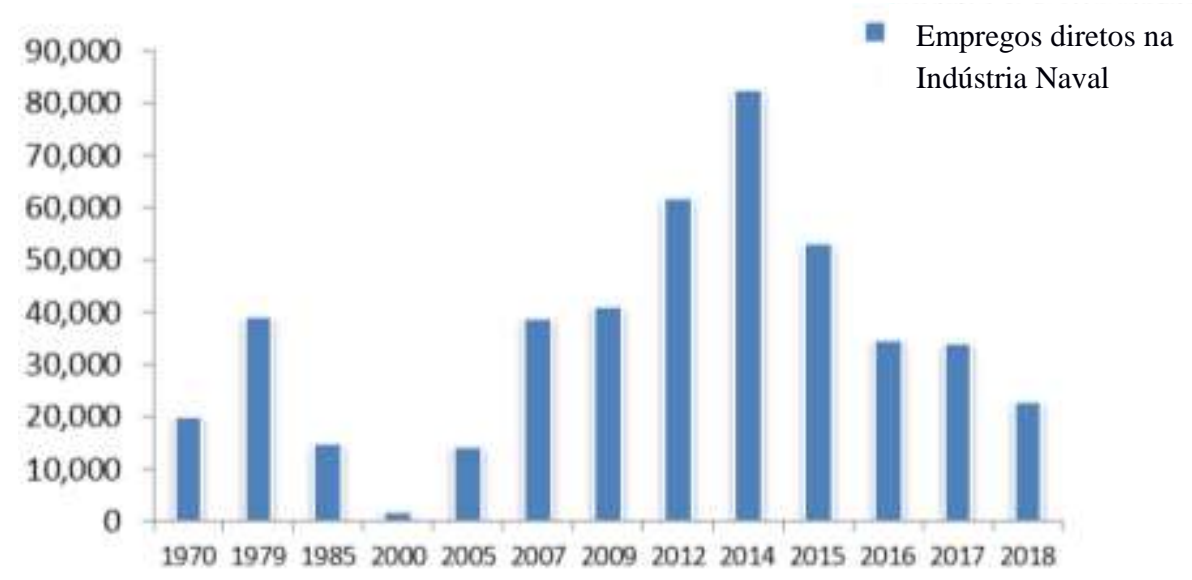

Fonte: Sinaval (http://sinaval.org.br/empregos/).

Respondendo às políticas governamentais em vigor no período 2007-2013 e à realidade do Pré-Sal, houve de fato uma mobilização de recursos que gerou aumento da capacidade instalada e contratação nas empresas fornecedoras, muito em torno dos investimentos da Petrobras. $\mathrm{O}$ agravamento da situação financeira da companhia e a queda expressiva de seus investimentos, no entanto, provocaram desmobilização e capacidade ociosa nos fornecedores.

A Tabela 2 registra a forte queda de emprego nas empresas fornecedoras no triênio 20142016, superior à perda geral de empregos industriais. A Tabela 3 especifica a queda dos empregos anuais nos fornecedores da Petrobras no mesmo período.

Tabela 2

Evolução empregos geral na indústria e das empresas fornecedoras da Petrobras

\begin{tabular}{l|c|c|c}
\hline & $2007-2013$ & $2014-2016$ & Variação \% \\
\hline Média anual dos trabalhadores nas empresas fornecedoras & 923.516 & 794.606 & $-31 \%$ \\
\hline Média geral dos trabalhadores da indústria & 4.945 .090 & 5.350 .307 & $-10 \%$ \\
\hline
\end{tabular}

Fonte: DISEP/IPEA a partir do cadastro de fornecedores da Petrobrás e da Relação Anual de Informações Sociais $\left(\right.$ RAIS/TEM) ${ }^{23}$. Elaboração própria.

Obs. a variação se refere ao último ano da mostra com relação ao primeiro.

(23) A pesquisa foi e baseada nas seguintes CNAE's 3 dígitos: 281 - Fabricação de motores, bombas, compressores e equipamentos de transmissão; 28.2 Fabricação de máquinas e equipamentos de uso geral; 28.5 Fabricação de máquinas e equipamentos de uso na extração mineral e na construção; 28.6 Fabricação de máquinas e equipamentos de uso industrial específico; 30.1 Construção de embarcações; 30.9 Fabricação de equipamentos de transporte não especificados anteriormente; 33.1 Manutenção e reparação de máquinas e equipamentos; 33.2 Instalação de máquinas e equipamentos; 42.2 Obras de infraestrutura para energia elétrica, telecomunicações, água, esgoto e transporte por dutos; 42.9 Construção de outras obras de infraestrutura; 43.2 Instalações elétricas, hidráulicas e outras instalações em construções; 50.1 Transporte marítimo de cabotagem e longo curso; 50.2 Transporte por navegação interior; 50.3 Navegação de apoio; 50.9 Outros transportes aquaviários; 71.1 Serviços de arquitetura e engenharia e atividades técnicas relacionadas; 71.2 Testes e análises técnicas. 
Tabela 3

Total de trabalhadores e taxa de crescimento do emprego nas empresas fornecedoras da Petrobras entre 2014 e 2016

\begin{tabular}{c|c|c}
\hline Ano & Total de trabalhadores fornecedoras & Taxa de crescimento \\
\hline 2014 & $901.191,41$ & $-8 \%$ \\
\hline 2015 & $816.460,01$ & $-10 \%$ \\
\hline 2016 & $666.166,95$ & $-19 \%$ \\
\hline
\end{tabular}

Fonte: DISEP/IPEA a partir do cadastro de fornecedores da Petrobrás e da Relação Anual de Informações Sociais (RAIS/TEM). Elaboração própria.

Diante desse quadro, os setores contrários à política de CL aproveitaram para aumentar a pressão, explicitando que seria o momento oportuno para ajustes. Em maio de 2015, na véspera da definição das regras para a $13^{a}$ Rodada, o IBP lançou uma nova ofensiva contra o CL, sempre com o argumento de destravar os investimentos (Ramalho, 2015). As exigências de CL teriam se tornado uma barreira para a retomada dos aportes. Essa argumentação sensibilizou, inclusive, as autoridades de Rio de Janeiro e Espírito Santo, estados com graves problemas orçamentários, que se interessaram na possibilidade de contar rapidamente com os recursos dos royalties. Daí a defesa da política do governo Temer por Paulo Hartung (2017), então governador do Espírito Santo, que se posicionou por mudanças drásticas no que chamou de "regras protecionistas e anacrônicas, que não preservam o real interesse do povo brasileiro". Alegou que as regras de CL "resultam em enormes atrasos na entrega de plataformas e equipamentos, produzidos a custo muito superior ao internacional", desestimulando os investimentos. Observa-se a sintonia fina entre essa opinião e o posicionamento e os argumentos do IBP.

Nesse momento, a indústria nacional, em particular a Federação das Indústrias do Estado de São Paulo (Fiesp), a qual estava, por motivos políticos, envolvida com o processo de desestabilização do governo Dilma, não se manifestou em defesa do CL. Tratava-se de uma política vista como parte do receituário de receitas intervencionistas dos governos do PT.

A própria presidente Dilma resolveu, tardiamente, criar abertura para um processo de discussão, visando o aperfeiçoamento do CL. Em janeiro de 2016, criou o Programa de Estímulo à Competitividade da Cadeia Produtiva, ao Desenvolvimento e ao Aprimoramento de Fornecedores do Setor de Petróleo e Gás Natural (Pedefor). De acordo com o artigo primeiro do Decreto 8.637, a estratégia tinha como objetivo:

Elevar a competitividade da cadeia produtiva de fornecedores no País; estimular a engenharia nacional; promover a inovação tecnológica em segmentos estratégicos; ampliar a cadeia de fornecedores de bens, serviços e sistemas produzidos no País; ampliar o nível de conteúdo local dos fornecedores já instalados; e estimular a criação de empresas de base tecnológica. (Brasil, 2016).

O Decreto flexibilizou o CL, incorporando várias propostas efetuadas por entidades empresariais. Em particular, as petrolíferas puderam, a partir de então, incluir no cálculo de CL, além de compra de bens e serviços, seus investimentos na expansão da capacidade produtiva e no processo 
de inovação tecnológica de fornecedores. Também poderia ser considerada como CL a compra de bens e sistemas ${ }^{24}$ no país, para exportação. Na prática, seria uma forma de compensar a dificuldade para se cumprir os índices de nacionalização contratados, evitar multas e pedidos de waiver.

Outra questão diz respeito à coordenação interna no governo. Setores empresariais vinham reclamando da exclusão ao longo do tempo do Ministério do Desenvolvimento, Indústria e Comércio Exterior (MDIC) dos debates e da formulação de políticas, com o qual tinham tradicionalmente mais interlocução. As decisões com relação ao CL tinham ficado concentradas no MME (FIEB, 2015, p. 17), daí a importância de a presidente Dilma ter dado a coordenação do Pedefor para o MDIC.

De certa forma, esse decreto veio para sofisticar o CL. O Pedefor era coerente com o espírito das políticas que vinham sendo implementadas desde o Prominp. As medidas tinham potencial para incentivar empresas a exportar a tecnologia desenvolvida no país e induzir as petrolíferas a formar sociedades com fornecedores locais. Em todo caso, não eram baseadas em uma avaliação rigorosa e abrangente da política por parte do Executivo. Pelo calendário político, poderia parecer um recuo e uma tentativa de efetuar um compromisso com as críticas menos radicais. Alguns meses depois, o Congresso iria aprovar o impeachment.

\section{Governo Temer e o desmonte 2016-2018}

O governo Temer priorizou a abertura das áreas do Pré-Sal para empresas internacionais e uma rápida monetização. Para isso, foi elaborado um calendário acelerado, com cinco rodadas no Pré-Sal e duas no pós-sal no período 2017-201825.

Além de sancionar alterações na Lei da Partilha, que tiraram a obrigatoriedade da Petrobras ser operadora única e o percentual de participação mínima em todos os consórcios no polígono do Pré-Sal, a nova direção da empresa iniciou um processo de desinvestimento. O governo entendeu também que a atração das empresas internacionais demandava maiores isenções fiscais para as operadoras e uma mudança drástica da política de CL.

Neste momento, a união do empresariado e das elites que surgira em torno do impeachment da presidente Dilma, se dividiu em dois campos: um que aceitava as linhas gerais da nova política para o $P \& G$ do governo Temer, mas defendia a manutenção de uma política de defesa da indústria nacional, e outro mais claramente liberal, que apontava para um desmantelamento total da política de CL. Essa divergência se refletia inclusive dentro do próprio governo Temer.

Um levantamento das manifestações públicas organizadas a respeito do CL aponta o surgimento de um núcleo duro em torno do Instituto Brasileiro de Petróleo (IBP) ${ }^{26}$, que, com apoio

(24) Os "sistemas" se referem a um conjunto de equipamentos, máquinas e materiais que realiza uma função específica.

(25) Ao final foram realizadas quatro Rodadas do Pré-Sal, porque o governo Temer não conseguiu organizar em tempo o leilão do Excedente da Cessão Onerosa.

(26) A leitura dos cables do consulado dos Estados Unidos de 2008 e 2009 vazados pelo Wikileaks já apontava o IBP como o centro de articulação da resistência às propostas que estavam sendo elaboradas para o marco regulatório (Wikileaks, 2013). 
dos lobbies de governos dos países de origem das principais multinacionais interessadas no Pré-Sal ${ }^{27} \mathrm{e}$ das correntes mais liberais do pensamento econômico brasileiro, defendia uma mudança radical de política, com índices de CL o mais baixos possíveis, desmonte da fiscalização (considerada burocrática, ineficiente e custosa) e defesa da retroatividade. Dentro do governo federal, essa posição encontrou simpatia na Fazenda, na Casa Civil e no próprio MME.

Já os setores que defendiam um aperfeiçoamento na linha do Pedefor, mas mantendo o espírito das políticas implementadas e, sobretudo, respeitando os contratos existentes, concentraramse no MDIC, BNDES e na Financiadora de Estudos e Projetos (Finep). ${ }^{28}$

No Quadro 1, vê-se as reduções nos índices de CL implementadas pelo governo Temer, com a publicação da Resolução n. 7 do CNPE, em 11 de abril de 2017, que foi aplicada à $14^{\text {a }}$ Rodada do pós-sal e às $2^{\mathrm{a}}$ e $3^{\mathrm{a}}$ Rodadas do Pré-Sal, todas realizadas em 2017.

Quadro 1

Comparação índices de CL para exploração, desenvolvimento e produção no mar entre o governo Dilma e o governo Temer (abril 2017)

\begin{tabular}{|l|c|c|}
\hline Conteúdo Local & Governo Dilma & Governo Temer \\
\hline Fase de Exploração & $37 \%-55 \%$ & $18 \%$ \\
\hline Fase de Desenvolvimento: Sistemas de coleta e escoamento & $55 \%-65 \%$ & $40 \%$ \\
\hline Fase de Desenvolvimento: Construção Poços & $55 \%-65 \%$ & $25 \%$ \\
\hline Plataformas & $55 \%-65 \%$ & $25 \%$ \\
\hline
\end{tabular}

Fonte: ANP e Resolução $7^{\circ}$ do CNPE de 11 de abril de 2017.

O CL deixou também de ser fator de pontuação das ofertas nos leilões. Houve um entendimento por parte do governo Temer de que isso teria gerado distorções entre promessa e realidade, contribuindo para a inviabilidade do cumprimento dos índices contratados. Observa-se, nesse ponto, que o contrato padrão para a partilha, desenvolvido entre 2011 e 2013, aplicado ao campo de Libra, já não tinha CL como fator de julgamento das ofertas vencedoras.

Esses parâmetros utilizados nos leilões realizados em 2017 suscitaram o debate fora e dentro do governo. Uma nota intitulada "Abimaq em defesa do Conteúdo local" fala em uma "decisão descabida de flexibilização da exigência de Conteúdo Local" e proclama "lutar pela indústria fornecedora de máquinas para o setor de óleo e gás e manutenção dos empregos no país".

Para entender o posicionamento dos diferentes setores, é importante diferenciar os quatro macrossegmentos (Quadro 2).

(27) Assim, por exemplo, baseado em telegramas do próprio Ministério das Relações Exteriores britânico que foram encaminhados erroneamente para Greenpeace, o jornal The Guardian constatou que "Britain successfully lobbied Brazil on behalf of BP and Shell to address the oil giants' concerns over Brazilian taxation, environmental regulation and rules on using local firms". Nessa correspondência, os diplomatas britânicos classificaram o enfraquecimento do conteúdo local "a principal objective" dos interesses britânicos (Vaughan, 2017).

(28) Essa divisão interna no governo Temer ficaria mais clara a partir das discussões no Comitê Diretivo do Pedefor (Rittner; Polito, 2017). 
Quadro 2

Macrossegmentos

\begin{tabular}{|c|c|}
\hline Segmento & Produção \\
\hline Operador & Petróleo e gás \\
\hline $\begin{array}{l}\text { Fornecedores especializados em Exploração e } \\
\text { Produção de Petróleo e Gás (para-petrolíferas). }\end{array}$ & $\begin{array}{l}\text { Sondas e serviços de perfuração; equipamentos e } \\
\text { instalações submarinas; unidades de produção e serviços } \\
\text { de operação, entre outros. }\end{array}$ \\
\hline $\begin{array}{l}\text { Fornecedores diretos. } \\
\text { Trabalham também com } \\
\text { componentes necessários para as petroleiras e os } \\
\text { fornecedores especializados. }\end{array}$ & $\begin{array}{l}\text { Tubulações, equipamentos eletrônicos, produtos } \\
\text { químicos, etc. }\end{array}$ \\
\hline $\begin{array}{l}\text { Fornecedores indiretos } \\
\text { Fornecem para os fornecedores diretos. }\end{array}$ & Siderurgia, petroquímica, forjados, etc. \\
\hline
\end{tabular}

Fonte: Elaboração própria.

No caso das fornecedoras especializadas, trata-se na maioria de subsidiárias de multinacionais, organizadas no Brasil na AbesPetro, criada em 2004 a partir do IBP e com 45 associados. Com a realidade do Pré-Sal, praticamente todos os grandes fornecedores internacionais especializados se instalaram no Brasil. A AbesPetro apoiou as alterações promovidas pelo governo Temer, com forte interesse em estimular maior participação das grandes empresas internacionais de petróleo.

De outro lado, se destacam a Abimaq (Associação Brasileira da Indústria de Máquinas e Equipamentos), o Sinaval e o Aço Brasil, que se manifestaram de forma mais permanente em defesa da manutenção de uma política de CL. As federações industriais dos estados mais afetados, como a Fiesp e a Firjan, acabaram se posicionando também nessa linha, diante da radicalidade da ofensiva do IBP. Nota-se, de outro lado, um posicionamento mais político-ideológico da Confederação Nacional da Indústria (CNI), que critica o CL pelo viés intervencionista.

Embora o governo Temer tenha iniciado a discussão sobre a alteração da política de CL em setembro 2016, a indústria nacional afetada começou a se mobilizar de forma organizada somente a partir de dezembro, criando o Movimento Produz Brasil. Faziam parte dele sete federações de indústrias (RJ, SP, SC, RS, MG, ES e BA) e um conjunto de associações de classe, com destaque para Abimaq e Sinaval. Com o lema Mais Indústria, Mais Empregos, Mais Brasil, o movimento tinha como foco a valorização do CL e a preservação dos investimentos realizados no país, sua capacidade produtiva e os empregos gerados pelas demandas atendidas. Havia grande preocupação com os investimentos já realizados em capacidade produtiva. Uma nota da Abimaq a respeito do seu lançamento explicita sua motivação:

Diante da recente ameaça de mudança na política nacional de petróleo e gás, instituições representativas dos elos produtivos deste mercado temem que investimentos realizados ao longo de quase 20 anos sejam jogados fora favorecendo empresas estrangeiras e tornando ainda mais difícil a situação da indústria (ABIMAQ, 2016).

A Fiesp também se manifestou contrária ao argumento de que o CL teria sido a causa dos atrasos nos investimentos: 
Pelo contrário, observa-se pelos dados dos resultados dos leilões que a partir da $7^{\mathrm{a}}$ rodada (de 2005 a 2015), quando as regras de conteúdo local eram mais específicas, arrecadouse mais valores em bônus e mais áreas foram arrematadas percentualmente e em tamanho (Coelho, 2017, p. ii).

Contestando a tese do então presidente da Petrobras, Pedro Parente (2017), de que a CL teria sido a materialização do intervencionismo estatal, o presidente da Fiesp, Paulo Skaf (2017), retrucou que: "É um equívoco afirmar que a política de conteúdo local impôs prejuízo significativo ao governo e ao setor de óleo e gás. Não há dúvidas de que a medida precisa ser aperfeiçoada, mas os resultados obtidos são expressivos".

Observa-se que, embora o movimento sindical, em particular os petroleiros e metalúrgicos, tenham se posicionado desde sempre fortemente em defesa do conteúdo local, assim como os congressistas dos partidos de Esquerda, as organizações empresariais articuladas em torno do Movimento Produz Brasil em nenhum momento tentaram uma aproximação.

As reivindicações das operadoras foram além da revisão dos índices e afrouxamento da sua aplicação, porque isso valeria somente para os contratos futuros, ao exigir aplicação retroativa da reforma, por meio de aditamentos aos contratos existentes. A experiência do campo de Libra, campo gigante na Bacia de Santos, objeto da primeira rodada do Pré-Sal organizada em outubro 2013, abriria caminho. O consórcio vencedor do leilão ${ }^{29}$ teve seu contrato com a ANP assinado em dezembro de 2013 dentro dos parâmetros dos índices de CL do governo Dilma. Para a fase de desenvolvimento da produção estava previsto o índice de 55\% a 59\%, o que significaria que a construção da plataforma de produção - unidade flutuante de produção, armazenamento e transferência (FPSO na sigla inglesa) deveria se dar no Brasil.

A Petrobras estava operando até então no Pré-Sal com índices de CL baixos e flexíveis, porque se tratavam de blocos contratados a partir dos primeiros leilões da ANP no início da década de 2000. Em agosto de 2014, houve a perfuração do poço exploratório e um ano depois iniciou-se o processo para o projeto definitivo de produção, lançando o processo de aquisição de uma FPSO para garantir a produção de 180 mil bpd em 2020, com somente dois poços furados, o que mostrou o ritmo que a Petrobras naquele momento quis imprimir.

Em depoimento durante o $1^{\circ}$ Fórum Técnico Pré-Sal Petróleo, organizado em novembro de 2018 pela estatal Pré-Sal Petróleo S.A. (PPSA), o então gerente executivo de Libra, Fernando Borges (2018), afirmou que a Petrobras teria recebido propostas $60 \%$ acima das referências dos preços do mercado internacional ${ }^{30}$. Observa-se que, na época, o consórcio alegava sobrepreço de $40 \%$, o que sempre foi contestado pelo principal interessado no país, o Estaleiro Atlântico Sul (EAS), e pela própria Sinaval, que chegou a ganhar uma liminar proibindo a licitação da plataforma no exterior. De toda forma, o alardeado sobrepreço foi a justificativa para se aproveitar o novo ambiente político e em agosto de 2016 cancelar o processo de compra.

(29) Petrobras (40\%), Shell (20\%), Total (20\%), China National Petroleum Corporation - CNPC (10\%) e China National Offshore Oil Corporation - CNOOC $(10 \%)$

(30) Foi o mesmo Fernando Borges que classificou o CL como "um grande perturbador do processo decisório" durante audiência pública realizado em março de 2017 pela ANP sobre o pedido de waiver no caso da Libra. 
Em seguida, o consórcio iniciou um pedido de waiver que foi concedido pela ANP no primeiro semestre de 2017, para o consórcio poder relicitar o FPSO com índices significativamente menores. A partir de então, parcela expressivamente menor dessa plataforma foi construída no Brasil (na prática, somente os serviços de integração dos módulos) ${ }^{31}$. O próprio presidente da Petrobras, em entrevista para o jornal Valor Econômico, apresentou como justificativa da concessão do waiver: "Em 2013, havia uma expectativa de que a indústria de fornecedores se desenvolvesse para que os percentuais de conteúdo local previstos no contrato de partilha estabelecidos fossem atingidos", e concluiu que isso não teria acontecido (Ramalho, 2017). A grande questão era que os altos índices de CL para as FPSO eram parte de uma política mais ampla que visava capacitar estaleiros no Brasil a construir os cascos. Porém, os estaleiros que tinham capacidade de construção dessa estrutura entraram em recuperação judicial, foram desmobilizados e perderam experiência e equipes qualificadas. Trata-se, portanto, de uma construção interrompida bruscamente.

Em abril 2018, a ANP abriu a possibilidade de aditamento generalizado da cláusula de CL dos contratos de concessão até a $13^{\circ}$ Rodada, da Cessão Onerosa e do primeiro leilão da partilha (Libra). Os novos parâmetros levaram em conta os pleitos dos fornecedores referentes à Resolução n. 7 do CNPE. Os percentuais mínimos da Resolução ANP n. 726/2018 estão representados no Quadro 3:

Quadro 3

Percentagens mínimas da Resolução ANP n. 726/2018, 12 de abril de 2018

\begin{tabular}{|c|c|c|c|c|}
\hline \multirow{2}{*}{$\begin{array}{l}\text { On-shore } \\
\text { (terra) }\end{array}$} & Desenvolvimento & & & $50 \%$ \\
\hline & Produção & & & $50 \%$ \\
\hline \multirow{6}{*}{$\begin{array}{l}\text { Off-shore } \\
\text { (mar) }\end{array}$} & Exploração & & & $18 \%$ \\
\hline & \multirow{5}{*}{ Desenvolvimento } & Construção de poços & & $25 \%$ \\
\hline & & $\begin{array}{l}\text { Sistema de coleta e } \\
\text { escoamento }\end{array}$ & & $40 \%$ \\
\hline & & \multirow{3}{*}{$\begin{array}{l}\text { Unidade estacionária de } \\
\text { produção (plataformas) }\end{array}$} & Engenharia & $40 \%$ \\
\hline & & & Máquinas e Equipamentos & $40 \%$ \\
\hline & & & $\begin{array}{l}\text { Construção, integração e } \\
\text { montagem }\end{array}$ & $40 \%$ \\
\hline
\end{tabular}

Fonte: ANP. Elaboração própria.

Embora significativamente inferiores aos parâmetros dos contratos originais (ver Quadro 1), a Abimaq considerou os resultados um avanço frente à proposta original de um índice global de $40 \%$ de CL sem distinção entre bens e serviços. Os fornecedores acabaram apostando na chegada de novos operadores na esperança de que a ampliação dos negócios gerasse uma demanda interna que pudesse compensar a perda do CL.

Contudo, até o final do governo Temer, mais de 200 pedidos de revisão de contrato relativos a mais de 400 blocos e campos foram aprovados pela ANP. A indústria naval foi a mais prejudicada com as novas regras, sobretudo porque os índices podem ser alcançados com os cascos produzidos

(31) Em dezembro 2017, o contrato foi assinado com a japonesa Modec, que acabou subcontratando somente um módulo, no caso para a Brasfels, em Angra dos Reis (Ramalho; Bôas, 2018). 
fora do país. A Sinaval tentou sensibilizar o TCU com o argumento de que houve quebra de contrato. A entidade também lançou uma publicação durante a campanha eleitoral de 2018 com o intuito de provocar um debate, sem muito êxito. A publicação lembra que o setor naval crescia entre 2000 e 2013 nada menos que 19,5\% ao ano, em média. Entre 2007 e 2016, foram construídas 605 embarcações e nove plataformas. Especificamente sobre o CL, aponta:

Muito foi investido e produzido graças à política de conteúdo local no Brasil e é possível fazer muito mais nessa nova fase de exploração do petróleo no País, aprimorando as regras, não excluindo. O conteúdo local precisa ser visto como uma política de Estado que traz benefícios ao País. (Sinaval, 2018, p. 15).

\section{Considerações finais}

Nos governos Lula e Dilma, o CL era uma política prioritária que tinha o objetivo de transformar a riqueza do petróleo em algo que pudesse extrapolar a produção em si e contribuir com o desenvolvimento produtivo do país. A centralidade da Petrobras na produção de $\mathrm{P} \& \mathrm{G}$ foi reforçada porque os governos a consideravam fundamental para viabilizar essa política de médio-longo prazo em detrimento de interesses comerciais e financeiros de curto prazo. O CL aumentou significativamente, gerando renda e trabalho. Pouco conseguiu se avançar para aumentar a capacidade inovativa e os investimentos em P\&D nas empresas fornecedoras. A pactuação que marcou o início do governo Lula em torno do Prominp foi se desfazendo, e a burocracia estatal começou a seguir uma lógica nem sempre articulada com o setor produtivo envolvido. Ao mesmo tempo, uma série de questões até mais estruturais, tais como câmbio e juros, iriam na contramão de uma política industrial proativa, e o CL começou a servir somente para compensar esses fatores.

Havia, portanto, no início do segundo governo Dilma, uma necessidade de repactuar essa política, a partir de uma avaliação ampla e rigorosa dos erros e acertos. Uma das questões que justificava o aperfeiçoamento da política de CL dizia respeito à necessidade de melhorar o foco e as prioridades relativas a segmentos e produtos. Por exemplo, levando em conta a geração de competências que possam ser utilizadas em outras atividades ou que tenham potencial para competir internacionalmente. O risco era de que a política de CL caísse nas armadilhas da velha política de substituição de importações com reserva de mercado e rent seeking. No fundo, a política de CL deveria ser construída a partir da (potencial) oferta, e não da demanda, como acabou prevalecendo. Ou seja, trabalhar com um "conteúdo local vocacional" - privilegiando segmentos com maior potencial para aumentar a produtividade.

A tese de que o CL seria o fator principal da paralisação do setor, porém, não se sustenta. Primeiro, há de se lembrar o impacto global da queda brutal dos preços do petróleo, que provocaram uma paralisação generalizada dos investimentos em $\mathrm{P} \& \mathrm{G}$ em nível global. Os investimentos no final de 2016 eram em termos nominais pouco mais da metade do volume de 2014. Segundo, houve, no caso específico do Brasil, o impacto devastador da Operação Lava-Jato, que interrompeu do dia para a noite uma série de empreendimentos, desarticulando cadeias de fornecimento inteiras. E, terceiro, houve uma recessão da economia brasileira como um todo devido a outros fatores. Portanto, é altamente questionável sugerir que a política de CL teria afetado a $13^{\circ}$ Rodada, realizada em outubro de 2015, a qual teria mostrado o pouco apetite dos investidores internacionais. 
Esses aspectos reforçam a noção de que os atores contrários ao CL aproveitaram a crise política e econômica que se instalou no Brasil, e no setor de $\mathrm{P} \& \mathrm{G}$ em específico, para avançar com sua agenda de liberalização e flexibilização. As alterações efetuadas no governo Temer não eram fruto de uma avaliação da política visando o seu aperfeiçoamento, mas refletiam uma visão que apostava na abertura do Pré-Sal para as empresas internacionais, em articulação com os interesses nacionais e internacionais das mesmas.

Ao mesmo tempo, a indústria local tinha se tornado muitas vezes protagonista de campanhas contra o governo Dilma, começando a se envolver na defesa do CL somente no final de 2016 e início 2017, quando o governo Temer tentou desestruturar a política por completo. É o caso, por exemplo, da Fiesp.

De certa forma, vários segmentos beneficiados pelo CL, como a indústria naval, estavam ainda passando por uma curva de (re)aprendizagem, gerando massa crítica. Embora houvesse claramente a necessidade de se organizar melhor as políticas de indução da capacidade tecnológica da base de fornecedores, articulando as políticas tecnológicas, inclusive os financiamentos da Finep, não há como, com a política de CL, sustentar a hipótese de que a própria política de CL teria inibido o aumento da capacidade tecnológica. Havia, portanto, a necessidade e a possibilidade de promover um aperfeiçoamento, e não necessariamente, como acabou sendo a linha do governo Temer, um desmonte. A comparação com a experiência norueguesa, pese à semelhança das ferramentas operacionais e normativas utilizadas, mostra a importância da continuidade das políticas ao longo das décadas, com ajustes e acréscimos em um processo de erros e acertos a partir de objetivos gerais claros e pactuados.

\section{Referências bibliográficas}

ABIMAQ. Produz Brasil: em prol da indústria e de mais empregos. São Paulo, 8 dez. 2016. Disponível em: $\quad$ http://www.abimaq.org.br/site.aspx/detalhes-imprensa-ultimosreleases?codNoticia=DBh03jltXN4=. Acesso em: 10 maio 2018.

ANP. Índice de Consultas e Audiências Públicas 2011. Disponível em: http://www.anp.gov.br/consultas-audiencias-publicas/371-indice/4810-indice-de-consultas-eaudiencias-publicas-2011. Acesso em: 15 dez. 2018.

BACCI, Sergio. A estratégia brasileira de produção de petróleo do pré-sal (Palestra). $57^{\circ}$ Fórum Brasilianas. São Paulo, 31 mar. 2015.

BRASIL. Decreto n. 8.637, de 15 de janeiro de 2016. Institui o Programa de Estímulo à Competitividade da Cadeia Produtiva, ao Desenvolvimento e ao Aprimoramento de Fornecedores do Setor de Petróleo e Gás Natural. Diário Oficial da União, Brasília, 18 jan. 2016. Disponível: http://www.planalto.gov.br/CCIVIL 03/ Ato2015-2018/2016/Decreto/D8637.htm\#view. Acesso em: 15 maio 2018. 
BRASIL. Presidenta (2011-2016: Dilma Rousseff) Discurso por ocasião da cerimônia de batismo da Plataforma P-56. Angra dos Reis-RJ, 3 jun. 2011. Disponível em: http://www.biblioteca.presidencia.gov.br/discursos/discursos-da-presidenta/discurso-da-presidentada-republica-dilma-rousseff-durante-cerimonia-de-batismo-da-plataforma-p-56. Acesso em: 15 jan. 2018.

BRASIL. Lei n. 12.351, de 22 de dezembro de 2010. Dispõe sobre a exploração e a produção de petróleo, de gás natural e de outros hidrocarbonetos fluidos, sob o regime de partilha de produção, em áreas do pré-sal e em áreas estratégicas; cria o Fundo Social - FS e dispõe sobre sua estrutura e fontes de recursos. Diário Oficial da União, Brasília, DF, 13 dez. 2010. p. 1.

BORGES, Fernando. Regime de Partilha de Produção 5+10: lições aprendidas e cenário futuro. $1^{\circ}$ Fórum Técnico Pré-Sal Petróleo (PPSA), realizado no dia 22 de novembro de 2018. Rio de Janeiro. Disponível em: https://www.youtube.com/watch?time continue $=6520 \& v=0 C r O g l Z D k X E$. Acesso em: 30 nov. 2018.

CANÊDO PINHEIRO, Mauricio. A recente política industrial brasileira foi bem desenhada? In: BARBOSA, Nelson; MARCONI, Nelson; CANÊDO-PINHEIRO, Mauricio; CARVALHO, Laura (Org.). Indústria e desenvolvimento produtivo no Brasil. Rio de Janeiro: Elsevier, 2015, v. 1.

CHANG, Há-Joon. Regulation of Foreign Investment in Historical perspective. The European Journal of Development Research, v. 16, n. 3, Autumn 2004a.

CHANG, Há-Joon. Chutando a escada: a estratégia do desenvolvimento em perspectiva histórica. São Paulo: Editora Unesp, 2004b.

COELHO, José Ricardo Roriz. A política de conteúdo local na indústria de Petróleo e Gás Natural. Departamento de Competitividade e Tecnologia/Fiesp. São Paulo: Fiesp, 2017.

FERNÁNDEZ Y FERNÁNDEZ, Eloi. Indústria nacional de bens e serviços nos arranjos produtivos do setor de óleo e gás natural no Brasil. In: GIAMBIAGI, Fábio; LUCAS, Luiz Paulo V. Petróleo. Reforma e contrarreforma do setor petrolífero brasileiro. Rio de Janeiro: Elsevier, 2013.

FERNÁNDEZ Y FERNÁNDEZ, Eloi; PEDROSA, Oswaldo. A Petrobras e o Conteúdo Local. Revista Brasil Energia, Rio de Janeiro, Edição Especial, out. 2003.

FIEB. A Política Brasileira de Conteúdo Local para o Setor de Petróleo e Gás. Análise e Sugestões de Aperfeiçoamento. Salvador, 2015.

FURTADO, André T.; FREITAS, Adriana G. Nacionalismo e aprendizagem no Programa de Águas Profundas da Petrobras. Revista Brasileira de Inovação. v. III, n. 1, mar. 2004.

FURTADO, André. T.; MARZANI, Bianca; PEREIRA, N. M. Política de compras da indústria do petróleo e gás natural e a capacitação dos fornecedores no Brasil: o mercado de equipamentos para o desenvolvimento de campos marítimos. In: PROJETO CTPETRO/ Tendência Tecnológicas. Rio de Janeiro, 2003.

FURTADO, Celso. Ensaios sobre a Venezuela: subdesenvolvimento com abundância de divisas. Rio de Janeiro: Contraponto/Centro Internacional Celso Furtado, 2008. 
Giorgio Romano Schutte

GHIRARDI, André Garcez. Petrobras: as causas da crise, além da Lava Jato. Outras Palavras, ago. 2015.

GUIMARÃES, Eduardo A. Política de conteúdo local na cadeia do petróleo e gás: uma visão sobre a evolução do instrumento e a percepção das empresas investidoras e produtoras de bens. Brasília: CNI, 2012.

HARTUNG, Paulo. Um momento decisivo para Petróleo e Gás. Um índice global de conteúdo local traria ganhos definitivos para o desenvolvimento. Valor Econômico. Opinião, A10. 6 fev. 2017.

HATAKENAKA, Sachi; WESTNES, Petter; GJELSVIK, Martin; LESTER, Richard. From 'Black Gold' to 'Human Gold'. A comparative case study of the transition from a resource based to a knowledge economy in Stavanger and Aberdeen. MIT Local Innovation Systems, Jul. 2006. (Working Paper, 06-002).

HEUM, Per. Local content development. Experiences from oil and gas activities in Norway. Bergen: Institute for Research in Economics and Business Administration, 2008. (Working Paper SNF, n. 1285).

KUMAR, N. Performance requirements as tools of development policy: lessons from experiences of developed and developing countries. New Delhi, 2013. (Discussion Paper, n. 52).

LESKINEN, Olivia; BEKKEN, Paul K.; RAZAFINJATOVO, Haja; GARCIA, MANUEL. Norway oil and gas cluster: a story of achieving success through supplier development. Microeconomics of Competitiveness. Havard Business School, May 2012.

LOURENÇO, Rafael. Modernizar o conteúdo local. Valor Econômico, 25 jun. 2014.

MENDONÇA, Roberto W.; OLIVEIRA, Luiz G. Local content policy in the Brazilian oil and gas sectoral system of innovation. Latin American Business Review, 2013.

NEGRI, João Alberto De (Coord.). Poder de compra da Petrobras: impactos econômicos nos seus fornecedores. Brasília: IPEA, 2010.

NORDAS, H.; VATNE, E.; HEUM, P. The upstream petroleum industry and local industrial development: a comparative study. Norway: Institute for Research in Economics and Business Administration, 2003. (SNF Report, 08/03).

OLIVEIRA Adilson de; ROCHA Frederico. Conclusões e recomendações de políticas. Estudo de Competitividade do Setor de P\&G Prominp 2009 - Ago/2011. IND-P\&G-28.

ORGANIZAÇÃO NACIONAL DA INDÚSTRIA DE PETRÓLEO. Oportunidades e desafios da agenda de competitividade para construção de uma política industrial na área de petróleo: propostas para um novo ciclo de desenvolvimento industrial. Rio de Janeiro: ONIP, 2010.

ORGANIZAÇÃO NACIONAL DA INDÚSTRIA DE PETRÓLEO. Impacto potencial da atividade da indústria de O\&G na sociedade brasileira. Rio de Janeiro: ONIP, 2008.

PARENTE, Pedro. Ranço ideológico e vida real. Folha de São Paulo, 1 fev. 2017. Disponível em: http://www1.folha.uol.com.br/opiniao/2017/02/1854701-ranco-ideologico-e-vida-real.shtml/.

Acesso em: 30 nov. 2018. 
PERES, Leandra. Governo americano quer menos conteúdo local no pré-sal. Valor Econômico, 10 abr. 2012.

PETROBRAS. Controle das contratações na Petrobras. Fato e Dados, 8 abr. 2014. Disponível em http://www.petrobras.com.br/fatos-e-dados-1/controle-das-contratacoes-na-petrobras.htm. Acesso em: 20 maio 2017.

PETROBRAS. Abertura de comissões para análise de aplicação de sanção administrativa e bloqueio cautelar. Fatos e Dados, 30 dez. 2014.

PETROBRAS. Plano de Negócios e Gestão 2012-2016. Rio de Janeiro, ago. 2012.

PETROBRAS. A presidenta da República, Dilma Rousseff, lança a plataforma P-56. Agência Petrobras, 31 maio 2011. Disponível em: https://www.agenciapetrobras.com.br/Materia/ExibirMateria?p_materia=10006. Acesso em: 10 fev. 2018

POLITO, Rodrigo. ANP mantém regras de conteúdo local em leilão. Valor Econômico, A4, 20 fev. 2013.

POMPERMAYER, Fabiano M. Modelo norueguês de desenvolvimento da cadeia de fornecedores da indústria do petróleo e sua aplicabilidade ao Brasil. IPEA, 2011. (Radar, n. 17).

PwC. O conteúdo local nos empreendimentos de Petróleo \& Gás natural. Sondagem, 2012.

RAMALHO, André. Sócios em Libra pressionam por flexibilidade do conteúdo local. Valor Econômico, B4, 23 mar. 2017.

RAMALHO, André. Lava-Jato traz oportunidade para revisão do conteúdo local, diz IBP. Valor Econômico, A4, 31 mar. 2015.

RIBEIRO, Cássio G.; FURTADO, André T. A política de compras da Petrobras: o caso da P-51. Revista Brasileira de Inovação, v. 14, n. 2, jul./dez. 2015.

SANTOS, Ricardo J. dos; AVELLAR, Ana Paul M. Políticas de apoio à indústria de petróleo e gás no Brasil: um estudo das ações públicas para o desenvolvimento da cadeia de valor. Economia e Sociedade, Campinas, v. 26, n. 3 (61), dez. 2017.

SASSON, Amir; BLOMGREN, Atle. Knowledge based oil and gas industry. Knowledge based Norway. Mar. 2011. (Relatório, n. 4).

SCHUTTE, Giorgio Romano. Petrobras em marcha forcada. São Paulo, 2016. (Textos para Discussão/NEEDDS, n. 001/2016

SCHUTTE, Giorgio Romano. O paciente holandês. Carta Capital, set. 2010.

SINDICATO DA INDÚSTRIA DA CONSTRUÇÃO E REPARAÇÃO NAVAL E OFFSHORE SINAVAL. Agenda do Sinaval para as eleições de 2018. Rio de Janeiro, 2018.

SINDICATO DA INDÚSTRIA DA CONSTRUÇÃO E REPARAÇÃO NAVAL E OFFSHORE SINAVAL. Apresentação do Sinaval na Audiência Pública da ANP. 18 abr. 2017. 
Giorgio Romano Schutte

SINDICATO DA INDÚSTRIA DA CONSTRUÇÃO E REPARAÇÃO NAVAL E OFFSHORE SINAVAL. A indústria da construção naval e o Desenvolvimento brasileiro. Rio de Janeiro, 2007.

SKAF, Paulo. O ranço ideológico e a indústria brasileira. Folha de São Paulo, 6 fev. 2017. Disponível em: http://www1.folha.uol.com.br/opiniao/2017/02/1855854-o-ranco-ideologico -e-a-industriabrasileira.shtml/. Acesso em: 15 abr. 2018.

THURBER, Mark C.; ISTADD, Benedicte T. Norway's evolving champion: statoil and the politics of state enterprise. Program on Energy and Sustainable Development, Stanford. May, 2010. (Working Paper, n. 92).

TRIBUNAL DE CONTAS DA UNIÃO (TCU). Avaliação da sistemática vigente da política de conteúdo local. Relatório Auditoria operacional. Brasília, 2015.

TRIBUNAL DE CONTAS DA UNIÃO (TCU). Fiscalização de conteúdo local. Identificação de oportunidades de melhoria. Relatório de auditoria operacional. Brasília, 2011.

TORDO, Silvana; WARNER, Michael; MANZANO, Osmel; ANOUTI, Yahya. Local content policies in the Oil and Gas sector. Washington: World Bank, 2013.

VAUGHAN, Adam. UK trade minister lobbied Brazil on behalf of oil giants. The Guardian, 19 Nov. 2017. Disponível em: https://www.theguardian.com/environment/2017/nov/19/uk-trade-ministerlobbied-brazil-on-behalf-of-oil-giants. Acesso em: 15 maio 2018. 